\title{
NID2 wt Allele
}

National Cancer Institute

\section{Source}

National Cancer Institute. NID2 wt Allele. NCI Thesaurus. Code C107105.

Human NID2 wild-type allele is located in the vicinity of $14 \mathrm{q} 22.1$ and is approximately 64 $\mathrm{kb}$ in length. This allele, which encodes nidogen-2 protein, is involved inmaintaining the structure of the basement membrane. 